\title{
11. The Impact of Transnationalism on Niue
}

\section{Vili Nosa}

\section{Introduction}

For many Pacific Islanders, migration is a positive opportunity for individuals to obtain higher standards of living and material possessions not available in their homelands. Pacific states, like many small countries, have come to depend increasingly upon larger metropolitan states such as New Zealand. However, this chapter shows that the consequences of individual migration decisions invariably impact upon the state of Niue, a small Pacific Island state known by its people as 'the rock of Polynesia'. Niue is one of the most extreme cases of depopulation in the Pacific region, in fact there are more Niueans living abroad, mainly in New Zealand, than on Niue. There are now real questions about whether a state with such a small population is economically and socially viable.

This chapter provides an outline of the effects of transnationalism on Niue and the Niueans who have settled in New Zealand. The reasons why Niueans have migrated in large numbers overseas especially to New Zealand is discussed, and the chapter also examines a number of key strategies currently being implemented in Niue to encourage Niueans abroad to return to their homeland.

\section{Background}

Available information about the early history of Niue is limited and the origins of Niuean society are not well documented. Loeb (1926), Smith (1983) and Thomson (1984) suggest that Niuean social structures were greatly influenced by the immigration of people from both eastern and western Polynesian cultures (including Tonga and Samoa). Later, European influences such as the London Missionary Society, early traders and 'blackbirders' were also evident. The work of Loeb (1926) and Kumitau and Hekau (1982) suggests that all of these influences have played major roles in shaping the ideologies of contemporary faka Niue (the Niue way). In fact, many of Niue's indigenous cultures and customs have been shaped by elements of the world view and lifestyles of the early Polynesian colonists, since even the most basic elements of Niuean society reflect influences and ideas similar to those present in societies such as Tonga and Samoa.

Niue is situated in Polynesia in the southwest Pacific Ocean and is the highest raised coral (makatea) island in the world. Niue is a single island housing 13 villages; the terrain is mainly steep limestone cliffs and a large proportion of the land is coral, much of it covered in indigenous forest and scrub. 
In 1900 Niue became a British protectorate; by 1901 it was annexed to the New Zealand administration where the latter had a major role in governing the economy of Niue. In 1974 Niue became a self-governed state with free association with New Zealand, and Niueans became New Zealand citizens with free rights into New Zealand (Chapman 1976; Government of Niue 1982). By 1986 the population of Niueans in New Zealand was 12,501 and by 2001 it was 20,148 (Statistics New Zealand 2006). The 2006 New Zealand census states that 22,473 Niueans reside in New Zealand, comprising 8 per cent of the New Zealand Pacific population. There was an increase of 2,325, or 12 per cent, since the 2001 census. Over 79 per cent $(17,667)$ of Niueans live in Auckland, which is an increase of 20 per cent since the 2001 census. Nearly three-quarters $(16,275)$ of Niueans were born in New Zealand. The Niuean population in New Zealand has therefore doubled in size, while in Niue, it has dropped to only 1,788 people (Statistics New Zealand 2006).

\section{Niuean Migration}

During the mid-19th century, Niueans joined the labour trade in Samoa, Tahiti, Hawaii, Fiji, and Australia. Many Niuean men emigrated to Samoa in order to work on the cotton plantations (Talagi 1991, 119). Mining was another factor in labour migration (both voluntary and involuntary); for example, in 1868 'blackbirders' such as Bully Hayes took 60 men and 30 women from Niue to work in the phosphate mines in Eastern Polynesia (Loeb 1926). Later, during the 20th century, labour migration increased due to the discovery of guano deposits on Malden Island in Kiribati (South Pacific Commission Report, 1983, No 11 Niue). This labour migration meant that large numbers of people were living away from Niue and other Pacific states. For example, more Wallis and Futuna shipping personnel worked in the New Caledonia nickel industry $(9,000)$ than in their own countries $(7,000)$. The phosphate mines in Nauru also employed Gilbertese and Ellice Islanders and Chinese from Hong Kong. Niuean migrants followed these trends and employment opportunities.

Military bases in the Pacific were also a staging arena for labour migration. For example, Filipinos in Guam were connected with the American military bases there. This created a movement from the Pacific towards America as intermarriage occurred between US service personal and Filipino residents. Since the 1900s, the USA has also recruited American Samoans into the Navy and Army, leading to more international Pacific migration. The relocation of military operations from American Samoa to Hawaii and California also led to major movements, as did similar trends in New Caledonia where France has a military presence. These recruitments and transfers are important for Pacific migration and have affected Niue given Niueans' informal (i.e., individual) involvement in military matters since World War I (Rex and Vivian 1982). 
Later phases of migration occurred after World War II when rapid growth in the larger states bordering the Pacific rim led to increasing demands for labour. In New Zealand, Australia and the US, employment opportunities generated larger scale international labour migration possibilities and heralded a change from migration within the Pacific to migration out of the region. It was during this period and under these circumstances that the major emigration from Niue occurred (Crocombe 1971).

The 1970s saw a trend towards major international Niuean migration. The opening of an international airport in 1971 established a transportation route that allowed easy movement in and out of Niue. Cheaper airfares in the 1980s ensured that individuals' ability to leave increased at a rapid rate. Another major factor was the process of 'internal self government' granted in free association with New Zealand in October 1974. This gave Niueans New Zealand citizenship. Between 1966 and 1984, Niue lost over 40 per cent of its population to Aotearoa. As Douglas notes, 'I would say that well over one-half of all Niueans at that point had decided to follow their impartial colonial administrators to Auckland rather than remain on the Island to be subjected to what they thought were the biases of their own people' $(1987,188)$. Moreover, the influence of the extended families already living in Auckland motivated other members to leave, which in turn created 'chain migration'.

The most common and significant motivations for migration from Pacific islands such as Niue are economic: the perceived rewards of employment, relatively high wages and the added bonus of a 'better' education system (Tuhega 1977). Writers such as Talagi (1991) have also suggested that a major factor in Pacific migration is the search for recreational activities such as cinemas and public bars, which become available with higher, more secure, personal incomes. Thus the features of migration from Pacific states such as Niue are complex and interlinked and we must be careful to avoid generalisations or simplifications of this dynamic phenomenon. Some factors are individualistic; for instance, Tuhega (1977) states that his parents decided to leave Niue because of land tenure problems and because education opportunities were limited for his children as only a small number of children were selected to go overseas on study scholarships. Political factors have also contributed to Niuean migration. Talagi suggests that 'the attitude of central government was that Niueans who were dissatisfied with government policies would be better off elsewhere - this was aimed at public servants in and the general population in general' (1991, 124; see also Douglas 1987).

The physical features of Niue also influence migration; Niue is a small atoll with limited resources. The physical resources of Niue are poor; available land is limited due to scrub and forest, and the high proportion of coral means that soil fertility is low. Water comes from bores and there are no running streams or 
rivers (Spoonley 1975; Talagi 1991). All of these factors mean that life in Niue largely revolves around the hard physical survival mode of plantation work. This involves clearing land for planting, weeding, nurturing and harvesting; all of which is done in the burning hot weather. Traditional cultivation methods are time consuming and hard to maintain. However, for many families, subsistence agriculture is a daily routine necessary to supplement the daily diet. This lifestyle is difficult and can encourage Niuean people to leave. The 'physically easier and relaxed lifestyle' found in New Zealand may be the principal 'pull factor' in Niuean migration to New Zealand (Douglas 1987). Even factory work can be perceived in terms of relative 'ease' compared with the tough life of 'bush work' on Niuean plantations (Talagi 1991).

Hurricanes and storms have played havoc with the economy of Niue. For example, Cyclone Ofa in 1990 practically devastated the island. Most homes and plantations were demolished, leaving many people homeless. The most recent cyclone that hit Niue was the Cyclone Heta in 2004, which destroyed a number of homes and land. For many, the only option was to leave. Niue's agricultural productivity is also affected by such weather patterns. In the early 1960s and 1970s, lime and passion fruit industries were developed. The 1980s saw the commercial production of coconut cream and in the 1990s taro production for export occurred. However, these agricultural ventures have not been successful for a number of reasons and Talagi suggests that morale among plantation growers has decreased, encouraging further migration (Talagi 1991). Today, agricultural production output is scarce and since only a few of the crops (such as taro) are exported, plantation growers are often frustrated by not gaining enough income to maintain a viable living. Added to this are the poor transportation facilities such as shipping services which only visit Niue once a month and air transport which occurs on a weekly basis. These problems with agricultural production may motivate international migration for landowners and non-landowners alike.

The colonial relationship between Niue and New Zealand has led to the influx of Western philosophies concerned with gaining social and economic opportunities found in Aotearoa. For example, the education system in Niue is limited in both resources and teaching facilities. Education is free and compulsory for all Niuean children, but currently there is only one primary school and one high school, and both primary and secondary curricula are based on the New Zealand system (with a few modifications). The standard education is set for the New Zealand National Certificate in Educational Achievement (NCEA). Only a few selected students are chosen for scholarships to enter New Zealand high schools. There are also the University of the South Pacific extension centre courses. For many youngsters growing up on Niue, the desire to remain at home in Niue is strongly linked to the availability of employment. For example, two young Niuean students interviewed for the Television New Zealand documentary Death on the Rock (Television New Zealand 1989) stated that if they were to gain 
employment with the government they would remain on Niue, however both suggested that the alternative was to migrate to New Zealand.

One other significant issue was the key decisions made by the first Niuean government. Funding that was allocated to particular firms did not develop to its full potential. For example, in one case, funding was given to the premier's son-in-law for projects that were not developed. One MP suggested that nepotism was a key issue at the time of funding these organisations (Television New Zealand 1989). This particular event also pushed many dissatisfied Niueans to migrate overseas.

\section{The Niuean Disapora}

During the early 1940s and 1950s, before planes could land on Niue, many Niueans travelled to New Zealand by ship. By 1974, when Niue became independent, planes were introduced, which saw a large influx of the Niuean population into New Zealand, particularly to Auckland. The main reason Niueans settled in Auckland was to be near immediate and extended family members who were already there, but as discussed above they were also drawn to what they saw as better lifestyle, education and employment opportunities, and the good weather. As already stated, there are now more Niueans in New Zealand than the on the island of Niue. Furthermore, there are more Niueans who are New Zealand-born, and there has been an increase in the number of Niueans with tertiary qualifications. Some Niueans have married members of other ethnic groups, such as Europeans and Maori, which is one factor leading to a decline in the spoken Niuean language (Statistics New Zealand 2006).

In recent years, the New Zealand economy has gone through some economic and social changes and the cost of living has become very high for many Niueans. In the past 10-15 years there has been a significant migration shift, with a large number of Niueans migrating to Australia. Even Niueans who had been living in New Zealand for the last 20-30 years have moved. A number of cities in Australia, including Sydney, Brisbane and Melbourne, have seen an influx of Niueans mainly due to higher wages, better employment opportunities and better lifestyle. Wages are a lot higher in Australia for manual factory work than in New Zealand. Housing is also cheaper and a number of young couples have been able to purchase a brand new house, which they would not have been able to do in New Zealand. The process of chain migration means that many Niueans continue to move, to be with immediate and extended family members.

\section{Forms of Transnational Connections}

There have been a few difficulties in terms of transnational connections between Niueans in New Zealand and Niueans back home. Firstly, Niue is quite isolated and there is only one flight per week for Niueans or tourists. Return flights to Niue have also been expensive. A number of airlines have not been very 
successful, such as Nauru airlines in the 1970s, Royal Tongan Airlines in the 1980s and Polynesians airlines in the 1990s. In the mid-2000s, Air New Zealand became the preferred airline and the weekly flights at just a quarter of the previous price have been beneficial for the economy, with a slight increase in the number of tourists. Niueans can afford to return home to see family members more often than before.

In the past, letters and telegraphs were a popular source of communication for many Niueans. The telephone has also been another form of communication but this has been very expensive. Niueans only use the telephone for urgent matters such as contacting family members, funerals, and celebrations. With the influx of new technology, email has become a popular means by which Niueans overseas can communicate with other Niueans. Many Niuean homes now have access to email. There is also weekly news on the Niuean government website, updating major events and activities. This website Niue Ki Mua publishes news about government business, such as overseas travel by government members and public servants, who is looking after their portfolios, and who is going overseas for courses, conferences and meetings. There is also news about workshops occurring in Niue, public events such as show days, cultural events and other social gatherings. There are also messages from the Premier about key events and issues of government.

In a global context, there is a communication chat line called the Niue Global Community. This is a forum where Niueans communicate with other Niueans around the world to discuss and debate Niuean issues. All new members must register to be part of the discussion group and must have some Niuean ancestral connection. Applicants must provide their name, village, places of residence and employment status. This is then sent to the founder of the site, Niuean Frank Sioneholo and his moderators, who look after the website. Membership is based on the management's approval. The site also advertises key Niuean community events, cultural and social activities. Photographs of events are also displayed on the website and there is strict monitoring of the topics that are discussed.

Niuean newspapers have been another means of keeping up with events occurring in the Niuean community. The first Niue newspaper, the Niue Star, was established in 1993 and currently has its office in Auckland. The news items include events from Niue and New Zealand such as current events, politics, sports and other cultural activities. In the last five years, two more newspapers have emerged: the Niue Today which also publishes a number of key Niue events, and the Fakapuloa Tala Niue, another New Zealand based magazine which publishes community news, social events and sports events and is also online. All of these newspapers publish in both Niuean and English.

Niuean migrants frequently send remittances of both money and goods to kin in Niue. Container loads of products such as food, appliances and furniture are 
often sent home to families on a monthly or weekly basis. Sometimes when Niueans visit New Zealand they shop for large amounts of products such as non-perishable food products to send home on the supply ships. There appear to be no barriers to family connections back home except the difficulties of flights which are only once a week. Given that tourism is the main source of attracting people home, this is often difficult with no mid-week flights. However, many Niueans continue to visit Niue for special occasions and celebrations.

\section{Future Developments on Niue}

A number of key strategies have been implemented to try and rebuild the state of Niue. In the past, developing food products for export was the main strategy, however, a number of attempts, such as the lime and vanilla production during the 1960s, have not been successful due to financial constraints and political issues.

Currently, a business partnership with Reef Shipping and the Niue government has developed a few business ventures to try to rebuild Niue. In 2005 the noni product was implemented and introduced into Niue. The noni (Morinda Citrifolia) grows mainly in the Pacific Islands and its juice is consumed for healthy skin, joint mobility, digestion, energy levels and the immune system. The noni initiative is a joint venture between the Niue government and Reef Shipping, with a noni farm located in Vaiea and local Niueans growing noni on their family plantations. Another initiative is the fish processing factory. Fish is caught in the local fishing area and processed in the local factory then exported to New Zealand, European and other large metropolitan states. This venture is trying to expand but there is a very limited labour supply to work within the factories.

On a family visit to Niue in February 2006, I also had the opportunity to observe some of the developments with a relative of mine who is the co-coordinator of the Niue Island Organic Farmers' Association. During the tour around the islands, I saw the development of vanilla production. Many of the local farmers grow vanilla on their own plantations and around their homes. The vanilla products are grown organically, without pesticides, and then exported to Europe and the USA. This venture is labour intensive because of the hand pollination of crops and the large plantation sizes.

Another venture I observed was the young farmers' project which is targeting school leavers to assist them to establish and manage vanilla plantations, piggeries and vegetable farms. The overall aim is to ensure that these young farmers are able to produce these products on a commercial basis. One such initiative, which has been implemented to encourage young Niueans to return, is NEVAT (Niue experience of Vaka Atu Toa). The scheme provides an opportunity for young New Zealand-born Niueans to explore the Niuean culture and lifestyle for three 
months. They are given the opportunity to live the Niuean lifestyle and experience the language and culture of a Niuean.

\section{Return Migration}

The issue of return migration is a contentious topic for many Niueans in New Zealand and Niue. The former Premier of Niue, Young Vivian, constantly tries to attract Niueans overseas to return home. A number of employment schemes have been developed to attract them, but they have been largely unsuccessful. The Niuean government has sent a number of officials to investigate how to encourage or entice Niueans to return home. One initiative is bank loans from the Niue bank, made available for people to renovate their homes. There are other housing schemes such as renovating houses in partnership with government, which are then rented to tourists. However, to date, these schemes have had little impact on the number of Niueans returning home.

Niueans are more likely to return for a holiday, for between one and four weeks. Elderly Niueans living on superannuation often return home for periods of two to three months then go back to New Zealand. Many elderly Niueans return to Niue during the New Zealand winter months. There is also a strong sense of family connections for many Niueans who live overseas. They often visit family members back home, particularly over the Christmas and New Year period. There are also village celebrations that occur once a month, where a number of stalls are set up to sell cooked food, raw food products from plantations and handicrafts such as woven hats, mats and handbags. This is an opportunity for the whole village to showcase and display a number of products. Many Niueans affiliated to a particular village will return for this celebration. There is a strong sense of village loyalty for Niueans overseas to attend these functions. Other important events are the family cultural celebrations such as weddings, twenty-first birthday parties, hair cutting and ear piercing ceremonies, for which many Niueans make the journey home. These celebrations are an important part of many Niueans' cultural identity and sense of belonging to Niue.

Land disputes are another major reason why there are a large number of Niueans returning from overseas, to reclaim their land. Land disputes have been a major issue for many Niueans and will continue. The economic development of land is very difficult as most Niueans are overseas and therefore there must be a consensus decision before any land is made available for development. In some cases, Niueans have returned to claim their land and some people have remained on the island to build new homes.

Despite Niue's efforts to establish jobs and opportunities in Niue, there has been little progress in encouraging Niueans abroad to return home. There are a number of key reasons for this: many individuals find it difficult to return to Niue because of the lower standard of living there compared with that in New Zealand. The 
cost of food in the shops is high, as are petrol prices. Another reason is pay parity and disparity of employment opportunities. There is a large pay disparity between, say, a local Niuean school teacher and a New Zealand-trained school teacher. As mentioned earlier in this paper, the difficulty of living in a subsistence agricultural economy is due to the nature of the land. The task of cultivating plantations is very difficult because of the density of coral land. Irrigation and watering of crops is also an issue, as is the problem of pests and wild pigs destroying plantations.

Access to healthcare services is another issue where services may not be adequate, therefore patients with major health complications are sent to New Zealand for further care. In terms of the education system, students who do not get scholarships often do not get the opportunity for further education so they migrate to New Zealand. For many parents, education is an important part of their children's educational development.

Despite the many factors discouraging return, a small number have returned home. Some Niueans have returned because of the stress of day-to-day living in New Zealand. For some, the costs of living have been quite high and they have had the added pressure of living in a demanding environment and surviving on poor pay. On a trip to Niue in 2006, many Niueans with whom I spoke were enjoying the laid-back lifestyle and stress-free environment. They had no immediate plans to return to New Zealand.

Magnall's (2004) thesis on the portability of returning Niueans on superannuation showed that they were only getting 50 per cent of their New Zealand superannuation. Participants in the study found it very difficult to retire to Niue. The author identified a number of key reasons why many elderly Niueans do not return home. Participants who had a home to return to, money to build a house and a spouse who was keen to join them were willing to return. On the other hand, participants who were not keen to return home had no home to go to and their spouses were not keen to join them. Those who have returned comment on the good climate and relaxed lifestyle (Magnall 2004). Participants also mentioned that the difficulty in returning to Niue was the process of upgrading their houses with modern indoor facilities such as toilets and showers. They also had to consider growing plantations and working the physical environment. The subsistence farming lifestyle is very difficult for the elderly. One result is that elderly parents also took their children and grandchildren back to Niue to help them.

On a trip to Niue with the governor general of Niue in April 2007 a group of New Zealand-raised and born young Niuean professionals met with the Niue government to explain their views on returning to Niue. Many of them highlighted the fact that they would not return to Niue because of the low wages, the high costs of living and the difficulties of raising families. However, many 
Niueans still have strong family connections and a sense of belonging, making them want to return to Niue one day.

\section{Discussion}

There is a significant trend for Niueans to migrate overseas and consequently, the population of Niue has declined rapidly. Many Niueans have migrated for better lifestyle opportunities, mainly to New Zealand. There is a large population of Niueans in Auckland and there are now more New Zealand Niueans with multiethnic backgrounds. Niueans have now moved to other parts of the world, especially to Australia, as employment opportunities are better and the cost of living is a lower than in New Zealand.

Transnationalism has played an important role for many of these Niueans abroad, who are still strongly connected with Niue through remittances, reciprocal gift giving, cultural activities, land obligations, and identity through kinship ties and obligations. Many Niueans will return for important events and to visit family. However, as highlighted in this chapter, Niue is an extreme case whereby a large population of Niueans live overseas and maintaining their transnational ties has been made difficult by inadequate transportation and expensive phone calls. Today, many Niueans have turned to technology to enable them to maintain these links through emails and the use of video conference technologies such as skype.

A number of key issues have been discussed in this chapter in relation to return migration. The government has created initiatives to repopulate Niue and in some cases, Niueans have returned to Niue because of the climate and laid back lifestyle, a stress free environment and the low cost of living. However, the problem of population decline remains and there are still a number of young people who feel that they will not return to the island because of low wages, the high cost of living and the change of lifestyle.

In the last five years, Niue has been slowly trying to rebuild its economy with the new initiatives that have been highlighted in this paper; it remains to be seen whether these are successful in the long term. For Niue to become an economically sustainable country it needs to have a strong financial base to ensure that resources are manageable and to develop the country. There also needs to be a good governance structure in place so that the economy is stable. Economic development needs to be strong so that Niue is economically viable and not reliant on overseas aid. Social services such as education and health services infrastructure also must be improved so that Niueans will have a better lifestyle in Niue and more Niueans will be willing to return home. 


\section{References}

Chapman M. T. 1976. The decolonisation of Niue. Wellington, New Zealand: Victoria University Press and New Zealand Institute of International Affairs.

Crocombe R. 1971. The Cook, Niue and Tokelau Islands. Fragmentation and emigration. In Land Tenure in the Pacific, ed. R. Crocombe, 60-89. Melbourne: Oxford University Press.

Douglas, H. 1987. Niue: The silent village green. In Class and culture in the South Pacific, ed. A. Hooper, 186-93. Suva: University of Auckland and Institute of Pacific Studies, University of South Pacific.

Government of Niue. 1982. Niue: History of the island. Suva: Institute of the South Pacific of the University of the South Pacific, Institute of Pacific Studies, University of the South Pacific.

Kumitau, V. and M. Hekau. 1982. Origins of the Niue people. In Niue: History of the island, ed. Government of Niue Institute of Pacific Studies, 82-90. Suva: University of the South Pacific and the Government of Niue.

Loeb, D. E. 1926. History and traditions of Niue. Honolulu: Bernice P Bishop.

Magnall, K. 2004. Retiring to Niue. MA thesis, Auckland University, NZ.

McDowell, K. D. 1961. A History of Niue. MA thesis, University of Auckland, NZ.

Rex, L. and Y. Vivian. 1982. The New Zealand period. In Niue: History of the island, ed. Government of Niue, 127-39. Suva: Institute of Pacific Studies, University of the South Pacific.

Smith, S. P. 1983. Niue: The island and its people. Suva: The Institute of Pacific Studies and the Niue Extension Centre of the University of the South Pacific, Suva. [Originally published in The Journal of Polynesian Society 11 (12): 1-113, 1902-3.]

South Pacific Commission report. 1983. Niue. Noumea: South Pacific Commission. Spoonley, P. 1975. Prospects for the Niuean community in Auckland: The role of gatekeeper groups in migrant adaptation. MA diss., University of Otago.

Statistics New Zealand. 2006. New Zealand Census of Population and Dwellings. Wellington: Statistics New Zealand.

Talagi, M. 1991. Contemporary politics of micro-state Niue. MA thesis, Auckland University, NZ.

Television New Zealand. 1989. Frontline: Death on the Rock. Television New Zealand Wellington. 
Migration and Transnationalism: Pacific Perspectives

Thomson, B. 1984. Savage islands: An account of a sojourn in Niue and Tonga. Papakura, New Zealand: McMillan.

Tuhega, L. 1977. Land tenure in Niue. In Land tenure in Niue, ed. S. Kalauni, R. Crocombe, L. Tuhega, N. Douglas, P. Pihigia, G. Leonard, and E. Lipitoa, 25-32. Suva: Fiji Times \& Herald Ltd, Institute of Pacific Studies, University of the South Pacific. 